\title{
Polski kontekst historii filozofii ukrainskiej: problemy i perspektywy
}

Historycy filozofii skłonni są ujmować narodowe tradycje filozoficzne jako ciagłe i samodzielne - jako takie, których fenomeny sa oryginalne, a swoje pojawienie się zawdzięczają przede wszystkim kulturze narodowej. Przy takim rozumieniu problemu logicznym przedmiotem badań byłyby wpływy lub współoddziaływanie dwu narodowych tradycji filozoficznych (łącznie ze wzajemna recepcja pewnych idei i teorii) albo problemy historiografii dwu filozofii narodowych $\mathrm{w}$ ujęciu porównawczym ${ }^{2}$. Nawet pobieżne spojrzenie na historię takiej filozofii jak ukraińska pokazuje jednak, że duża część jej idei, nurtów, a nawet postaci jest wspólna $z$ innymi filozofiami narodowymi: reprezentowane tutaj dzieła pisane były w różnych językach, w różnych kontekstach politycznych i kulturowych, pod wpływem ogólnoeuropejskich czy regionalnych nurtów ideowych. Niniejszy artykuł jest próbą ukazania, że ze względu na wspomniane okoliczności badanie instytucji, prądów umysłowych i postaci, bez

Serhij Josypenko (ORCID 0000-0001-5928-6638) - doktor habilitowany, kierownik Zakładu Historii Filozofii Ukrainy w Instytucie Filozofii im. Hryhorija Skoworody Narodowej Akademii Nauk Ukrainy.

1 Artykuł powstał na bazie referatu wygłoszonego na IX Seminarium Filozofii Polskiej „Konteksty lokalne i uniwersalne", które odbyło się 21 września 2017 roku w Instytucie Filozofii Uniwersytetu Jagiellońskiego.

$2 \mathrm{Ku}$ problematyce komparatystycznego badania polskiej i ukraińskiej filozofii zwracałem się w artykule: S. Rudenko, S. Yosypenko, National philosophy as a subject of comparative research, „Sententiae” 2018, nr 37 (1), s. 120-129. 
których trudno wyobrazić sobie dzisiaj kanon ${ }^{3}$ filozofii ukraińskiej, wymaga rozpatrywania nie tylko kontekstu własnego, ukraińskiego, ale także polskiego. Jego istnienie wiąże się $z$ tym, co Wilen Gorski (1931-2007) określił w artykule Ukrainsko-polska „strefa wspólna” i jej znaczenie dla historii filozofii ukrainskiej mianem „strefy wspólnej jako jednej przestrzeni kulturowej dla obu narodów"4. Gorski skupił się na opisie pewnych aspektów tej strefy wspólnej, natomiast przedmiotem mojego artykułu będzie analiza problemów współczesnej historiografii filozofii ukraińskiej w odniesieniu do instytucji, prądów umysłowych i postaci, które do tej strefy należą.

Rozpatrywanie historii filozofii ukraińskiej albo jej poszczególnych fenomenów w kontekście intelektualnej, politycznej lub kulturowej historii sasiedniego narodu nie jest niczym nowym. $Z$ uwagi na warunki powstania historiografii filozofii ukraińskiej jako dyscypliny w XX wieku spora część charakterystycznych dla niej zjawisk tradycyjnie postrzegana jest w kontekście rosyjskim; na polski patrzy się natomiast głównie przez pryzmat konfliktu ukraińskiej i polskiej tożsamości i wciąż pozostaje on na Ukrainie słabo zbadany. Paradoksalnie nie brakuje oczywistych przykładów wspólnych odniesień i wzajemnego wpływania na siebie tych dwóch narodowych tradycji filozoficznych, rozwijajaccych się często w jednej i tej samej przestrzeni geograficznej. Za taki stan rzeczy odpowiada szereg czynników, których wyjaśnienie pozwoli określić kierunki badania polskiego kontekstu historii filozofii ukraińskiej i zrozumieć ich wyniki.

Współczesny nurt badań nad historia filozofii ukraińskiej rozpoczął się w latach czterdziestych XX wieku, w czasach filozofii radzieckiej. W latach czterdziestych i pięćdziesiątych pole badań historyków filozofii ukraińskiej było pod względem chronologicznym i merytorycznym dość wąskie. Zwracano wówczas uwagę głównie na działal-

\footnotetext{
3 Pod pojęciem kanon rozumiem zespół postaci, utworów i zjawisk zaliczanych do przedmiotu badan danej historiografii filozofii.

4 V. Gors'kij, Ukraïns'ko-pol's'ka „sfera spil'nosti”" ta ï̈ značennâ dlâ ìstoriï ukraïns'koï filosofiï, w: idem, Fìlosofiâ v ukraïns'kij kul'turì (metodologiâ ta istoriâ), Centr praktičnoï filosofiï, Kiïv 2001, s. 184.
} 
ność naukową ukraińskiego ruchu narodowego, rozwój materializmu oraz recepcje marksizmu w XIX i na poczatku XX wieku; zajmowano się takimi postaciami dawnej historii filozofii ukraińskiej jak Iwan Wyszeński (około 1550-1621) czy Hryhorij Skoworoda (1722-1794), którego zresztą władza radziecka oficjalnie uznała za najwybitniejszego ukraińskiego filozofa. Gdy w latach sześćdziesiątych XX wieku radzieccy historycy filozofii podjęli próbę rozszerzenia pola badań o cała epokę od Wyszeńskiego po Skoworodę, tłumaczyli to właśnie potrzebą zrozumienia, skąd wziął się tak wyjątkowy fenomen w historii filozofii ukraińskiej, jakim był Skoworoda. Okazało się to zabiegiem skutecznym, gdyż od tego czasu głównym przedmiotem badań nad całą wczesną nowożytnością stała się Akademia Kijowsko-Mohylańska - w niej bowiem kształcił się Skoworoda - oraz pisarze kręgu Akademii Kijowsko-Mohylańskiej5, których znaczenie dla rozwoju ukraińskiej filozofii i kultury mocno wówczas podkreślano.

Nawet po smutnych i tragicznych wydarzeniach 1972 roku represjonowaniu ukraińskiej humanistyki i zamknięciu licznych kierunków ukrainoznawczych - nie przerwano badań nad filozofia uprawiana w Akademii Kijowsko-Mohylańskiej. Zgodnie z oficjalną linia przedstawiano ja jednak odtąd jako pierwszy ośrodek naukowy na tak zwanych terenach wschodniosłowiańskich, wspierający rozwój wspólnej kultury bratnich narodów: Rosjan, Ukraińców i Białorusinów. Kolejny raz pole badań nad historią filozofii ukraińskiej rozszerzyło się w latach osiemdziesiątych XX wieku, kiedy w centrum uwagi znalazły się „idee filozoficzne kultury Rusi Kijowskiej”, uważanej - nie mogło być inaczej - za „kolebkę trzech bratnich narodów"'.

Takie warunki kształtowania się zainteresowań naukowych badaczy historii filozofii ukraińskiej dość dobrze tłumaczą, dlaczego

\footnotetext{
5 Termin ukuty przez Ryszarda Łużnego. Zob. R. Łużny, Pisarze kręgu Akademii Kijowsko-Mohylańskiej a literatura polska. $Z$ dziejów zwiazków kulturalnych polsko-wschodniosłowianskich $w$ XVII-XVIII $w$., Wydawnictwo Uniwersytetu Jagiellońskiego, Kraków 1966.

6 Zob. S. Josipenko, O. Vdovina, M. Simčič, İstoriâ filosofii Ukraïni âk galuz' naukovogo doslìdžennâ ì akademična disciplina v 1950-2000 rokah, „Sententiae” 2011, nr 2.
} 
ich uwadze nagminnie wymykał się kontekst polski. Trzymali się oni logiki tożsamości narodowej wyznaczonej przez dziewiętnastowieczna tradycję ukraińskiego romantyzmu i ruchu narodnickiego, którą $\mathrm{w}$ czasach radzieckich łączono $z$ dominującym paradygmatem, że historia Ukrainy to część historii Rosji. W tak uformowanej perspektywie pisarze kręgu Akademii Kijowsko-Mohylańskiej wydawali się elementem obcym, nienależącym do historii ukraińskiej, chyba że tworzyli w języku ludowym czy zaliczali się do „postępowych" nurtów myśli nowożytnej. Większość $z$ nich należała jednak do wyższego duchowieństwa, a ukraiński ruch narodnicki generalnie $z$ niechęcią odnosił się do stanów wyższych, zwłaszcza hierarchii kościelnej i tradycyjnych wspólnot kościelnych; otwarcie lub skrycie sympatyzował za to $z$ protestantyzmem. Dziewiętnastowieczny ukraiński ruch narodnicki był więc w swoim nastawieniu wobec religii podobny do późniejszej oficjalnej ideologii radzieckiej. Ta $z$ kolei odziedziczyła po dziwiętnastowiecznej historiografii rosyjskiej tendencję do wywyższania wszystkiego co prawosławne, wraz z nastawieniem antyzachodnim, w tym antypolskim. $Z$ tej układanki paradygmatów historiograficznych wyniknęło coś zaskakującego. Otóż niektórzy pisarze kręgu Akademii Kijowsko-Mohylańskiej należeli do duchowieństwa prawosławnego, które aktywnie przeciwstawiało się katolicyzacji i polonizacji wschodnich Słowian, i to oni zaczęli uchodzić w radzieckiej historiografii za element mniej lub bardziej postępowy. Wyniknęły $z$ tego dwie konsekwencje dla radzieckiego kanonu historii filozofii ukraińskiej: możliwość prowadzenia badań nad wkładem myślicieli religijnych w rozwój filozofii ukraińskiej oraz przeniknięcie całego kanonu przez tendencję konfesyjna.

Od początku lat dziewięćdziesiątych XX wieku badacze dawnej filozofii ukraińskiej unikają paradygmatów wywodzących się $z$ epoki radzieckiej. Zamiast tego kłada nacisk na elitarny charakter kultury kijowsko-mohylańskiej i jej znaczenie dla rozwoju kultury ukraińskiej. W mniejszym stopniu chwala zdolność akademii do przeciwstawiania się płynącym z Zachodu zagrożeniom dla tożsamości ukraińskiej, a w większym eksponuja rolę, jaką uczelnia ta odgry- 
wała w procesie przekazywania osiagnięć kultury zachodnioeuropejskiej na ziemie ukraińskie. Jedna $z$ najważniejszych badaczek tego tematu, Walerija Niczyk (1928-2002), w książce zatytułowanej Akademia Kijowsko-Mohylańska a kultura niemiecka następująco podsumowała swoje wieloletnie badania nad dorobkiem akademii: „Po pierwsze, Akademia Kijowsko-Mohylańska stała się ogólnoukraińskim ośrodkiem edukacji, nauki i kultury. [...] Po drugie, to właśnie dzięki niej Ukraińcy dokonali selektywnej syntezy duchowych, naukowych i kulturowych osiagnięć zarówno Zachodu, jak i Wschodu Europy, zapoznali się $z$ nimi i oswoili te $z$ nich, które odpowiadały tradycjom i aktualnym potrzebom ich własnej kultury”7. Podjęta przez Niczyk próba określenia dróg recepcji „duchowych, naukowych oraz kulturowych osiagnięć zarówno Zachodu, jak i Wschodu Europy" rozpoczęła się od renesansowych Włoch (rozdział 2) i skończyła na reformacyjnych Niemczech, którym autorka poświęca najwięcej uwagi (rozdziały 3-5). Zabrakło natomiast oddzielnego omówienia kontrreformacyjnej Polski, nie wspominając już o kontrreformacyjnych Włoszech i Niemczech. Zabrakło więc tej Polski, która stanowiła bezpośredni kontekst reform Piotra Mohyły, a co za tym idzie - założenia i prawie stuletniej działalności Akademii Kijowsko-Mohylańskiej. Niczyk nie zanegowała wprawdzie relacji łączących ten ośrodek $z$ Polska, jednak położyła akcent na to, że polski „wkład przypominał wprost zachodnia kontrreformację. Owszem, dawał o sobie znać również w refleksji i działalności Piotra Mohyły oraz ideach, które - zapoczątkowane przez Mohyłę - przyswiecały akademii i były głoszone na jej wykładach. Jednak ani te idee, ani treść wykładów nie wywodziły się w całości $z$ owego wkła$\mathrm{du}$, lecz razem $z$ nim tworzyły system [ukraińskiego] baroku, w którym obecne były liczne inne współzależne elementy"8.

Związek Akademii Mohylańskiej z renesansowymi Włochami opisano w znacznej mierze pod wpływem prac Wołodymyra Łytwynowa -

7 V. Ničik, Kiêvo-Mogilâns'ka akademiâ ì nìmec'ka kul'tura, Ukraïns'kij Centr duhovnoï kul'turi, Kiïv 2001, s. 14-15.

8 Ibidem, s. 22. 
badacza, który zapełnił lukę w historii filozofii ukraińskiej sięgająca od Rusi Kijowskiej do unii brzeskiej. Zasłużył się on jako inicjator i wydawca antologii Ukrainscy humaniści epoki Odrodzenia', a następnie opublikował monografię zatytułowana Humanizm renesansowy na Ukrainie ${ }^{10}$. Kanon historii filozofii ukraińskiej wzbogacił się dzięki tym pracom o takie postacie jak Jerzy Drohobycz (14501494), Paweł z Krosna (około 1470-1517), Stanisław Orzechowski (1513-1566) czy Maciej Stryjkowski (1547-1586/1593), a także o innych łacińsko- i polskojęzycznych autorów, którzy należą również do polskiego kanonu. Było to możliwe dzięki porzuceniu przez Łytwynowa archaicznego przekonania, że o tożsamości narodowej decydowała przynależność religijna czy językowa, i zastąpieniu go nowoczesnym rozumieniem tożsamości jako samostanowienia i samookreślenia.

W książce pod wymownym tytułem Ruś katolicka Łytwynow podkreślił, że należeli do niej „katolicy, którzy mieli świadomość narodowa, zdecydowanie określali siebie jako Ukraińców oraz deklarowali pochodzenie "ruskie»"11. W kolejnej pracy, poświęconej Stanisławowi Orzechowskiemu, rozszerzył to pojęcie o zasadę terytorialną:

[...] do autorów ukraińskich zaliczamy obecnie wszystkich, którzy, po pierwsze, w schemacie „my-oni” określali się jako Rusinów (Russus, Ruthenus, Roxolanus) w przynajmniej równym stopniu, w jakim określali się jako Polaków (Polonus) bądź Moskali (Moscovitus); po drugie, żyli na terenach etnicznie ukraińskich („od Sanu do Donu”), głównie w „województwie ruskim" w Polsce; po trzecie, byli Ukraińcami jakiegokolwiek wyznania, [w definicjach] odchodzimy bowiem od patriotyzmu wyznaniowego; po czwarte, byli Ukraińcami niezależnie od języka, w którym pisali swoje utwory ${ }^{12}$.

Łytwynow uwzględnił więc specyfikę decyzji konfesyjnych i językowych podejmowanych przez autorów wczesnej nowożytności, któ-

\footnotetext{
9 V. Litvinov (red.), Ukraïns'kì gumanisti epohi Vìdrodžennâ. Antologîa, č. 1-2, pereklad V. Litvinova, Naukova dumka / Osnovi, Kiïv 1995.

10 Idem, Renesansnij gumanizm v Ukraïnì (İdeï gumanizmu epohi Vìdrodžennâ $v$ ukraïns'kìj filosofii XV - počatku XVII st.), Kiïv 2000.

11 Idem, "Katolic'ka rus'" (Vnesok ukraïncìv katolic'kogo vìrospovìdannâ v duhovnu kul'turu Ukraïni XVI st.). İstoriko-filosofs'kij naris, Ukraïns'kij Centr duhovnoï kul'turi, Kiïv 2005, s. 4.

12 Idem, Stanislav Orihous'kij. İstoriko-filosofs'kij portret, Akademperiodika, Kiïv 2014, s. 6.
} 
re - inaczej niż w przypadku pisarzy żyjacych w późniejszych epokach - nie miały zwiazku $z$ tożsamością narodowa ${ }^{13}$. Moim zdaniem rozszerzył tym samym pole badań historii filozofii ukraińskiej w kierunku filozofii na Ukrainie ${ }^{14}$ i skorygował wcześniejsze ujęcia o tej ostatniej ${ }^{15}$. Jego definicja filozofii ukraińskiej okazała się jednak zbyt szeroka. Pisząc swoje książki, Łytwynow przedstawiał najpierw ogólna charakterystykę epoki, rekonstrukcję kontekstu intelektualnego oraz biografie filozofów, którzy "określali siebie samych jako Ukraińców". Następnie w opisie ich poglądów na Boga i przyrodę, człowieka i rozum ludzki, edukację i moralność, historię, państwo i naród stosował stary, dobrze znany paradygmat historiografii radzieckiej. Takie podejście nasuwa pytanie: czy zbiór utworów, idei i poglądów stanowi całość zwaną fi lozofią ukraińską tylko dlatego, że autorzy „określali siebie samych jako Ukraińców"? A nawet jeśli tak, to czy taki zbiór cechuje jakakolwiek specyfika? Czy opiera się on na czymkolwiek więcej niż tylko wspólnym pochodzeniu filozofów?

Rzecz jasna, w historii filozofii dystynkcje oparte na kryteriach narodowych rzadko kiedy zbiegaja się $z$ bazujacymi na kryteriach koncepcyjnych. Zbieżność obserwujemy w wyjątkowej sytuacji, gdy doświadczenie wspólnoty narodowej stanowi nie tylko kontekst, ale i przedmiot refleksji filozoficznej, jak miało to miejsce w polskiej filozofii narodowej czy ukraińskiej filozofii idei

\footnotetext{
13 Oczywiście, że we wczesnej nowożytności nie chodzi o tożsamość narodową w sensie współczesnym, ale o tożsamość jako poczucie przynależności do wspólnoty religijnej, językowej, historycznej, lokalnej lub politycznej i odrębność wobec innych takich wspólnot.

${ }_{14}$ Tu i w dalszej części tekstu stosuję podobną klasyfikację co Wiktor Wąsik (1883-1963): filozofia w Polsce, filozofia polska, polska filozofia narodowa. Zob. W. Wasik, Historia filozofii polskiej, t. 1: Scholastyka, Renesans, Oświecenie, Instytut Wydawniczy „Pax”, Warszawa 1958 , s. 14.

15 Na przykład w kontekście powstania Pro Ecclesia Christi ad Samuelem Matieiovium Stanisława Orzechowskiego znajduje podstawy do sprostowania tezy klasyka historii filozofii ukraińskiej Dmytra Czyżewskiego (1894-1977), który w utworze zatytułowanym Szkice o historii filozofii na Ukrainie (1931) stwierdzał, że nie ma dowodów znajomości przez Ukraińców „pierwszego protestanckiego systemu filozoficznego Filipa Melanchtona”. Zob. V. Litvinov, Stanislav Orihovs'kij..., s. 46-47; D. Čiževs'kij, Narisi z istorï filosofï na Ukraïnì, w: idem, Fìlosofs'kì tvori, t. 1, red. V. Lìsovij, Smoloskip, Kiïv 2005, s. 28. Warto tu jednak zaznaczyć, że wyobrażenia Czyżewskiego o ukraińskiej tożsamości narodowej po prostu nie przewidywały włączenia do historii filozofii na Ukrainie dorobku Ukraińców katolików.
} 
n a rodowej. Zbieżność możliwa jest także wtedy, gdy filozofowie pracuja $\mathrm{w}$ jasno określonym kontekście społecznym, uformowanym przez wspólny język, który wyklucza inne grupy społeczne czy wspólna instytucję, na przykład ośrodek naukowy, towarzystwo czy środowisko uczonych o charakterze świeckim bąź duchownym, szkolnictwo narodowe itp. Pisarze $z$ kręgu Akademii Kijowsko-Mohylańskiej niewątpliwie skupiali się wokół wspólnej instytucji, która wyznaczała im główne kierunki działalności, jednak nie zaistniała tu żadna jednorodna kultura, a ich idee nie stały się jednolite. Wspomniana wyżej Niczyk zawsze zauważała w kulturze mohylańskiej odrębne nurty.

Łytwynow nakreślił natomiast perspektywę, w której trudno o takim czymś mówić: ukute przez niego pojęcie Ruś katolicka odnosiło się bowiem do wspólnoty nominalnej, nie zaś realnej. W czasach Rzeczypospolitej katolicy pochodzenia ukraińskiego (podobnie zreszta jak protestanci) należeli także do innych wspólnot, opartych na różnych kryteriach, a zatem ich katolickie czy ruskie tożsamości miały ograniczone znaczenie. $Z$ drugiej strony nie wolno ignorować opisanych przez Łytwynowa kryteriów, na których zbudował pojęcie Ruś katolicka: publicznego przyznawania się autorów do swojego pochodzenia, podkreślania własnej odrębności, występowania w interesie wspólnoty i przywiazania do terytoriów ruskich wraz z ich tradycjami historycznymi. Chodzi tu więc o myślicieli, którzy publicznie działali w duchu humanizmu na rzecz wspólnoty obywatelskiej i jednocześnie brali udział w sporach religijnych, w których przykład kościoła wschodniego nie był pozbawiony pewnej atrakcyjności - był to bowiem kościół przodków. Wynika stąd, że określenie myślicieli Rusi katolickiej mianem tylko ukraińskich czy tylko polskich byłoby mniej lub bardziej jednostronne i nie oddawałoby $\mathrm{w}$ pełni istoty problemu.

Okazuje się więc, że w epoce przednowoczesnej przestrzenie, na styku których dokonywała się praca intelektualna i wymiana kulturowa, rzadko kiedy mieściły się w granicach narodowych. Nie oznacza to oczywiście, że przestrzenie te znosiłyby granice narodowe czy 
też zmuszały nas do porzucenia pojęciowych i zakresowych definicji narodów. Niemniej jednak, zwracając na te przestrzenie uwagę, możemy pozbyć się pewnych nieprzydatnych pojęć, zakładających istnienie kultury narodowej jako bytów samowystarczalnych i tożsamych wyłącznie $z$ samymi sobą, rozwijających się autonomicznie i prowadzacych wymianę $z$ innymi kulturami na podstawie odrębnego i niezmiennego substratu. Ze wszech miar przydatna okazuje się tu koncepcja Marca Crépona. Ten francuski filozof mówi o „z a sadniczo heterogenicznym charakterze tożsamości narodowych" i wyjaśnia to następująco:

Kultury europejskie nie sa sobie nawzajem wrogie i obce. Ich historia jest historia mędrców, uczonych, artystów i pisarzy, ale też historia realnych uwarunkowan - wojen, przymierzy dyplomatycznych, wymiany handlowej, wzajemnego wspierania się i walk między narodami - w jakich ze sobą współdziałały. Kultury te ciagle interpretują się nawzajem, prowadza wymianę, dokonują wzajemnych zapożyczeń i tłumaczą siebie nawzajem. Każda $z$ nich wyróżnia się nie tylko jakimś materialnym czy duchowym substratem, np. „krwia”, charakterem czy duchem, ale też swoimi relacjami z tym, co jest dla nich in ne, a zostało przez nie przyswojone... Ż a d n a kultura nie należy tylko do samej siebie ${ }^{16}$.

Zgodnie $z$ ta logika inności można stwierdzić, że wczesnonowożytna historia kultury polskiej jest częścia historii kultury ukraińskiej tak samo, jak ukraińska jest częścią polskiej. Ówcześni myśliciele, którzy postrzegali siebie jako Ukraińców albo - co więcej - jako myślicieli ukraińskich, mogli należeć do polskiej czy też jeszcze innej wspólnoty narodowej bądź ponadnarodowej, opartej na kryteriach, które niekoniecznie odpowiadaja tożsamościom dzisiejszych narodów.

O przydatności podejścia Crépona można się przekonać na przykładzie jednego ze wspomnianych czynników współtworzących pole wymiany kulturowej, a mianowicie języka, często traktowanego jako kryterium przynależności utworów literackich czy filozoficznych do

16 M. Crépon, Altérités de l'Europe, Galilée, Paris 2006, s. 57-58. 
kanonu narodowego. Gdy chcemy zastosować takie kryterium do literatury średniowiecznej i wczesnonowożytnej, natrafiamy na specyficzny opór. Zwrócił na to uwage polski literaturoznawca Andrzej Romanowski w pracy Literatura polsko-rusko-rosyjska? ${ }^{17}$. Pisarzy kręgu Akademii Kijowsko-Mohylańskiej - Łazarza Baranowicza, Symeona Połockiego, Joannicego Gałatowskiego, św. Dymitra Tuptałę, Stefana Jaworskiego i Teofana Prokopowicza - postrzega on jako całościowy fenomen historii literatury. Autorzy ci tworza bowiem symultanicznie bądź konsekutywnie w różnych językach, które są używane w ich środowisku. Co charakterystyczne, myśliciele rusińscy, to znaczy ukraińscy bądź białoruscy, używają języków rosyjskiego i polskiego obok łaciny, cerkiewnosłowiańskiego i tak zwanej prostej mowy ukraińskiej bądź białoruskiej. Fakt połączenia języka rosyjskiego $z$ polskim, a w konsekwencji zakorzenienia tych autorów w obu przestrzeniach kulturowych, mocno wyróżnia kulturę mohylańska w całym okresie od założenia akademii do trzeciej i czwartej dekady XVIII wieku.

Przydatny do opisania takich konstelacji paradygmat stosuje także białoruski badacz Walery Jewarouski. Rozszerza on jednak przedmiot badań pod względem geograficznym i chronologicznym. Terytorialny zasięg swoich dociekań Jewarouski definiuje jako region Wielkiego Księstwa Litewskiego (a zatem ziemie białoruskie, litewskie i ukraińskie), chronologicznie zaś skupia się na „przedziale czasowym od rozpadu Rusi Kijowskiej do rewolucji październikowej wraz z powstaniem Drugiej Rzeczypospolitej i Republiki Litewskiej w 1918 r. oraz Zwiąku Radzieckiego w 1922 r."18 Choć podejście Jewarouskiego okazuje się adekwatne do badania historii kultury białoruskiej (bądź litewskiej), to nie pasuje do ukraińskiej. Poza obszarem badań znalazłyby się bowiem tereny, na których kultury ukraińska i polska oddziaływały na siebie najdłużej, a mia-

\footnotetext{
17 A. Romanowski, Literatura polsko-rusko-rosyjska?, „Wielogłos. Pismo Wydziału Polonistyki UJ" 2016, nr 2 (28), s. 1-26.

18 V. Evaroŭski, Nacyânal'naâ filosofiâ Belarusì: tèoryâ, arheologîa, gìstoryâ, genealogîa, škola, Belaruskaâ navuka, Mìnsk 2014, s. 272-273.
} 
nowicie dawna Galicja (zwana województwem ruskim), pokrywajaca się $\mathrm{w}$ przybliżeniu $\mathrm{z}$ późniejszym austriackim krajem koronnym Królestwa Galicji i Lodomerii.

Przestrzeń wymiany kulturowej i przynależność do pewnej wspólnoty stanowi oczywiście tylko kontekst twórczości filozoficznej, który w bardzo różnej mierze wpływa na sposób ujmowania i rozwiązywania problemów filozoficznych. Dla historyka filozofii określenie i przeanalizowanie tego kontekstu jest jednak ważnym krokiem w drodze do obiektywnej i możliwie wszechstronnej interpretacji dzieł filozoficznych ze szczególnym uwzględnieniem ich źródeł, odbiorców, warunków powstawania i miejsca w intelektualnej biografii filozofa. Rekonstrukcja historii narodowej tradycji filozoficznej musi zatem zawierać opis obszarów dzielonych $z$ innymi kulturami i tradycjami narodowymi, szczególnie wtedy, gdy uwarunkowania narodowe czy kulturowe wpływaja nie tylko na biografię, ale i na meritum twórczości myśliciela.

$\mathrm{Na}$ koniec chciałbym przytoczyć jeszcze jeden $z$ szeregu szczególnie pouczających przykładów, opisany przez Stepana Iwanyka w pracy doktorskiej pod tytułem Ukrainska myśl filozoficzna w Galicji $w$ pierwszych trzech dekadach $X X w$. w kregu Szkoły Lwowskiej Kazimierza Twardowskiego, obronionej w 2011 roku w Instytucie Filozofii im. Hryhorija Skoworody Narodowej Akademii Nauk Ukrainy ${ }^{19}$. Podobnie jak Łytwynow w odniesieniu do myślicieli renesansowych, Iwanyk dowodzi, że Szkoła Lwowsko-Warszawska należy nie tylko do historii filozofii polskiej, lecz także do historii filozofii ukraińskiej, wśród jej członków byli bowiem również Ukraińcy, których prace $\mathrm{w}$ pełni odpowiadały teoretycznym założeniom szkoły. $Z$ drugiej strony - inaczej niż w szesnastowiecznym kontekście badanym przez Łytwynowa - w pierwszych dekadach XX wieku obok polskiej kultury i filozofii, a zarazem wspólnie $z$ nia, istniała w Galicji wyraźnie odrębna wspólnota ukraińska $-z$ wieloma instytucjami

19 Dopracowana i uzupełniona wersja tego tekstu opublikowana została później w języku polskim. Zob. S. Ivanyk, Filozofowie ukraińscy w Szkole Lwowsko-Warszawskiej, Wydawnictwo Naukowe „Semper”, Warszawa 2014. 
naukowymi, edukacyjnymi i oświatowymi, do których należeli protagoniści dysertacji Iwanyka. Szczególnie wyrazistym przykładem jest tu psycholog i filozof Stefan Baley (1885-1952) - absolwent Uniwersytetu Lwowskiego, uczeń Kazimierza Twardowskiego, który w 1928 roku został profesorem Uniwersytetu Warszawskiego, a w 1952 członkiem tytularnym PAN. Był również członkiem ukraińskiego Towarzystwa Naukowego im. Szewczenki, a w latach dwudziestych wykładał na Tajnym Uniwersytecie Ukraińskim we Lwowie. Pisał i publikował zarówno w języku polskim, jak i ukraińskim, tworzac dwa odrębne korpusy prac ${ }^{20}$. Nasuwa się wobec tego pytanie: Czy można badać twórczość Baleya w kontekście historii filozofii ukraińskiej, biorąc pod uwagę - jak często bywa - wyłącznie ukraińskojęzyczny korpus jego dzieł? Czy można badać jego ukraińskojęzyczne dzieła, nawet wspólnie z polskojęzycznymi, ale przy pominięciu polskiego kontekstu, w którym powstawały - tak starannie zrekonstruowanego przez Iwanyka?

W historii filozofii ukraińskiej zbyt dużo jest postaci i zjawisk rodzacych tego typu pytania, abyśmy mogli przeanalizować je raz a dobrze. Różnice między nimi są istotne, a wiele dzieł nie zostało dotąd przebadanych. Za taki stan rzeczy odpowiadaja między innymi wskazane tutaj i wciąż stosowane przez historyków filozofii ukraińskiej redukcje w pojmowaniu tożsamości narodowej. Znosząc je i uwzględniając polski kontekst historii filozofii ukraińskiej, możemy skorygować paradygmaty ukraińskiej historii intelektualnej, a w kolejnym kroku skoncypować taki jej kanon, w którym Ukraina ze swoim narodem będzie się jawić jako jeden $z$ krajów europejskich, który w swojej historii wielokroć współinicjował i prowadził obustronną wymianę kulturową i intelektualna $z$ innymi narodami (w szczególności $z$ sąsiednimi), tworząc razem $z$ nimi zróżnicowane przestrzenie wspólnoty kulturowej i intelektualnej. Takie podejście umożliwia nie tylko osiagnięcie lepszych rezultatów w badaniach nad tym, co wspólne dla Polaków i Ukraińców. Pozwala także prze-

20 Więcej zob. ibidem, s. 49-55. 
zwyciężyć odziedziczone wyobrażenia o zamkniętych w sobie tożsamościach narodowych i jak gdyby monadycznych substratach filozofii ukraińskiej, polskiej czy słowiańskiej.

Przekład z ukraińskiego Steffen Huber

\section{The Polish Context of the History of Ukrainian Philosophy: Problems and Perspectives}

The article analyses problems in the historiography of Ukrainian philosophy that emerge when research objects are institutions, currents of thought and persons, already included into the canon of Ukrainian philosophy. Their objective investigation, however, is impossible if the Polish context is not considered. This context is formed by the common sphere of Polish and Ukrainian histories. It includes figures and institutions important for both nations, such as Stanisław Orzechowski, the Kyiv-Mohyla Academy and the Lviv-Warsaw School. The author believes that research into the Polish context of the history of Ukrainian philosophy requires a revision of the inherited views on Ukrainian identity. The proposed concept can reject the view that the national philosophical tradition is a self-sufficient and original product of the national culture.

Keywords: Ukrainian philosophy, Polish philosophy, historiography of national philosophy, philosophical tradition, Kyiv-Mohyla Academy. 